\title{
PRIMERI UPORABE GIS PRI KATASTRU ODLAGALIŠČ ODPADKOV IN OCENJEVANJU NJIHOVE NEVARNOSTI
}

\author{
Igor Šebenik in Robert Špendl
}

UDK 628.4:91:681.3

\section{Izvleček}

Odlagališča odpadkov so $v$ Sloveniji množičen pojav. Šele $v$ zadnjih letih se jim posveča večja pozornost. Kmalu je postalo jasno, da je dobra evidenca-kataster odlagališč podlaga za programe sanacij odlagališč. Sanacije brez ustrezne dokumentacije so pomanjklive, saj se dogaja, da nekatera odlagališča preprosto zginejo, se zasujejo brez vednosti kaj smo zasuli ali s časom o zasuti lokaciji obstajajo le še nasprotujoč si ustna izročila. V taki situaciji je tehnologija GIS več kot dobrodošla za upravljanje s podatki o odlagališčih. Vsekakor je podatkouni sloj odlagališč odpadkov potreben GIS-u za upravljanje s prostorom. Dobro razvita računalniška atributiuna baza in grafični prikazi na merilih 1:5000 ali 1:10000 so pousem primerna podlaga za razvoj tega sloja. Na vodovarstvenem območju smo z PC ARC/INFO izdelali testni GIS. Za potrebe MVOUP Republike Slovenije pa se je izdelala aplikacija za povpraševanje po podatkih $v$ GeoSQL. Nadaljna poteza je ekspertni sistem za postopek prioritetizacije nevarnosti odlagališč za okolje na osnovi računalniške baze podatkov v GIS.

UDC $628.4: 91: 681.3$

\section{Abstract \\ APPLICATIONS OF GIS FOR THE CADASTER OF DUMPSITES AND THE DUMPSITES EVALUATION}

Dumpsites are in Slovenia mass phenomena but special attention for this problem is shown finally in last years. It became clear that a good cadaster is necessary for qualitative remediation programes. There's no documentation data, they are usually lost and only contradictory oral data are accessable. Technology of GIS seems to be very convenient for dumpsites data managing. The 'dumpsites layer' has to be fully used in environmental GIS. Well developed atribute data base and maps in scale 1:5000 or 1:10000 are a good base for a layer construction. A pilot GIS with this data was developed for water protection area of spring Rižana in year 1991. This year an application for data retrieval was developed for the needs of Mininstry for environmental protection and physical planning. Next step in establishing of system for dumpsites monitoring is a development of an expert system for the prioritisation of hazards dumpsites cause, based on the data collected in GIS.

Igor Šebenik, dipl. org. dela, Inštitut za geografijo Univerze v Ljubljani, Trg francoske revolucije 7 , Ljubljana in Robert Špendl, Oikos, Cankarjeva 4, Ljubljana 


\section{UVOD}

Odlagališča odpadkov so $\mathrm{v}$ Sloveniji množičen pojav v pokrajini. Njihovo število je odvisno od vrste dejavnikov, kot so uspešnost primernega ravnanja $z$ odpadki, raba zemljišč, primernost mikroreliefa... Njihovo število zajeto s popisom pa je odvisno od tega, kako velika odlagališča upoštevamo. Če smatramo za odlagališče odpadkov kraj $z$ vsaj $1 \mathrm{~m}^{3}$ odpadkov ali vsaj $5 \mathrm{~m}^{2}$ vidno zasmetene površine pride v 110 popolnoma pregledanih KS oziroma $7.5 \%$ slovenskega ozemlja $v$ povprečju 2.4 odlagališča na $\mathrm{km}^{2}$ in $3.83 \mathrm{~m}^{3}$ odpadkov na prebivalca. Približno $85 \%$ lokacij $\mathrm{z}$ manjšo količino odpadkov ima skupaj le $10 \%$ vseh odloženih odpadkov, medtem ko se večina odpadkov nahaja sicer na relativno manjšem deležu kljub temu ne maloštevilnih lokacij. Največ lokacij (približno 54\%) in količini odpadkov (približno $82 \%$ ) se nahaja v oddaljenosti med $100 \mathrm{~m}$ in $1000 \mathrm{~m}$ od naselij. Mikrolega in raba tal $v$ neposredni okolici odlagališča sta odvisni od velikosti odlagališča in od pokrajinskih danosti. Najpogostejše so lokacije v opuščenih gramoznicah, vrtačah, ob prometnicah na pobočju, v grapah, na bregovih vodotokov, $\mathrm{v}$ gozdu in $\mathrm{v}$ grmovju, na opuščenih površinah. Tudi sestava odpadkov je $\mathrm{v}$ večini primerov mešana, najpogosteje so to gospodinjski, gradbeni in veliki kosovni odpadki.

Zaradi obsega pojava je podatke o odlagališčih potrebno skrbno dokumetirati v t.i. kataster odlagališč, ki je običajno sestavljen iz dveh delov: grafičnega prikaza lokacije in samih podatkov o odlagališču. Način dokumentacije popisov, ki ga obravnavamo v tem članku, vsebuje vsaj enega od dveh kvantitativnih podatkov o lokaciji odlagališča: $\mathrm{X}, \mathrm{Y}$ koordinati $\mathrm{v}$ Gauss-Krugerjevi mreži na $5-10 \mathrm{~m}$ natančno in (ali) lokacijo na TTN 1:5000 ali 1:10000. Številka lokacije na karti se ujema s številko $v$ podatkovni bazi. To je dovolj dobra podlaga za sestavo sloja lokacij odlagališč v GIS.

Uporabniški softver za uporabo atributne baze podatkov in izrisane lokacije na TTN so bili $v$ okviru danih možnosti zaenkrat dovolj dobri mediji za nadaljno uporabo podatkov pri prioritizaciji nevarnosti odlagališč odpadkov na lokalnih nivojih. Brez globokega razmišljanja pa se je zdela uporaba teh podatkov $v$ okviru GIS potrebna in povsem mogoča. Vsebina GIS $s$ podatki o odlagališčih zavisi od namena uporabe. Torej, poleg popolne grafične in atributne baze podatkov o odlagališčih odpadkov potem lahko uporabljamo še druge sloje podatkov.

\section{BAZA PODATKOV O ODLAGALIŠČIH}

\section{VIRI PODATKOV}

Podatke o odlagališčih odpadkov pridobivamo s podrobnim terenskim pregledom in dokumentacijo $\mathrm{v}$ popisni list na terenu. Podoben terenski pregled se opravi s gorskim kolesom, mopedom in tudi peš. Delo je zamudno, 
popisovalec dnevno (približno 10 ur dela) pregleda od $5-8 \mathrm{~km}^{2}$, glede na zahtevnost terena. Pregledajo se vsi dostopni predeli v okolici naselij $z$ ozirom na lokalni relief in rabo tal, vsi robovi prometnic, bregovi vodotokov. Običajno se dnevno popiše približno 20-40 odlagališč. Sledi kabinetno urejanje in preverjanje podatkov, kjer se podatki pripravijo do take stopnje, da ni več potreben terenski ogled in da $v$ popolnosti ustrezajo uporabljanim kriterijem. Ti podatki se dopolnijo s podatki jamarskih društev. Sledi sestava baze podatkov na računalniku in izris kart.

Skupna baza podatkov (3591 zapisov 1.10.1992) vsebuje približno 5\% podatkov taborniške organizacije, ostali podatki so pridobljeni s profesionalnim delom preko pogodbenih del za nekatere slovenske občine.

\section{VSEBINA BAZE PODATKOV}

Podatki se nanašajo na naslednje značilnosti o:

legi odlagališča: $\mathrm{X}, \mathrm{Y}$, nadmorska višina, krajevna skupnost, bližnje naselje, širša in ožja lega $v$ reliefu, raba tal v okolici, bližina površinske vode, bližina naselja, geološka podlaga pod odlagališčem, dostop do odlagališča, lega znotraj zaščitenih območij,

lastnostih odlagališča: površina, količina odpadkov, vrsta odlagališča, stanje odlagališča, izpostavljenost odlagališča, vrsta odpadkov, razporeditev odpadkov,

prvi oceni vpliva odlagališča na okolico in možnosti odvoza odpadkov.

\section{ORGANIZACIJA IN DOKUMENTACIJA BAZE PODATKOV}

Vsi našteti podatki $z$ opisno vsebino so šifrirani, je pa tudi možnost dodatnega opisa $v$ tekstovnem polju. Baza podatkov se sestavi s pomočjo programa dBASE 3+. Lokacije odlagališč se običajno narišejo na transparente TTN 1:5000 ali 1:10000.

\section{PILOTNI-VZORČNI GIS ZA VODOVARSTVENO OBMOČJE IZVIRA RIŽANA}

Vodovarstveno območje izvira Rižana je veliko $247 \mathrm{~km}^{2}$. Meje potekajo na severu do vrha južnih pobočij Brkinov, na zahodu nekje do Kozine in približno do magistralne ceste Ljubljana-Koper vse do črnokalske stopnje, na jugu zajame še kraška polja pri Kubedu, Gračišču in Smokvici, od tu proti vzhodu pa meja poteka v dokaj ravni črti nekako do Pregarij na Brkinih. Leži deloma $v$ občinah Sežana in Koper, manjši del pa tudi v občini Ilirska Bistrica in na hrvaškem ozemlju. Razen južnih pobočij Brkinov in posameznih flišnih pasov je to kraški svet. Popis je tu pokazal 690 lokacij odlagališč. Pilotna študija GIS za vodovarstveno območje je zajela približno $30 \mathrm{~km}^{2}$ na njegovem zahodnem delu pri Kozini. To območ- 
je smo izbrali, ker je tu najizrazitejša koncentracija prebivalstva in dejavnosti znotraj vodovarstvenega obmocja.

Uporabljali smo PC ARC/INFO ver. 3.4D instaliran v podjetju GISDATA v Zagrebu. Osnovni sloj so bili podatki popisa odlagališč odpadkov (132 lokacij). Poleg lokacij odlagališč odpadkov smo s TTN 1:5000 vnesli še naslednje sloje:

- liki: obrise naselij, meje katastrskih občin, meje vodovarstvenih pasov,

- linije: prometnice (železnica, več kategorij cest, kolovoze),

- točke: lokacije kraških jam, kalov in izvirov.

Atributni podatki za odlagališča so obsegali približno 25 različnih podatkov, podatki za ostale sloje pa le npr. imena. Iz skupne baze podatkov smo po različnih kriterijih izrisali več kart $v$ različnh merilih (1:25000 in 1:50000). Izkazalo se je, da je večina odlagališč ob samem robu naselij, ob prometnicah ali vsaj ob kolovozih. Malo odlagališč ni ustrezalo tem zahtevam. Stanje je v naravi ponekod dokaj različno, kot na približno 20 let starih TTN, ki smo jih uporabljali za digitalizacijo. Ti TTN vsekskor ne morejo biti izključen vir podatkov za navedene grafične sloje.

\section{GIS ZA UPRAVLJANJE PODATKOVNE BAZE ODLAGALIŠČ ODPADKOV V SLOVENIJI}

Spomladi leta 1992 je družba OIKOS v sodelovanju z Ministrstvom za varstvo okolja in urejanje prostora izdelala GIS, s katerim želimo standardizirati obdelavo podatkov o odlagališčih odpadkov v Sloveniji. Pri nas namreč obstaja več metodologij popisa odlagališč odpadkov in $\mathbf{s}$ tem tudi več načinov shranjevanja podatkov. Poleg tega je GIS korak naprej $v$ informativnosti prikaza podatkov, kajti zemljevid $z$ vrisanimi odlagališči pove mnogo več kot opisni podatki in koordinate.

GIS je zgrajen na podlagi programa GeoSQL. Izbran je bil zaradi dostopnosti, cenenosti in enostavne uporabe, predvsem pa zaradi tega, ker je GeoSQL "most" med standardom za upravljanje podatkovne baze (ANSI SQL, v našem primeru Óracle) in "de facto" standardom za obdelavo za obdelavo grafičnih elementov (AutoCAD).

\section{STANDARDIZACIJA FORMATA}

Za vsak informacijski sistem je bistvenega pomena pravilno zasnovana podatkovna baza. Naš GIS se vsebinsko opira na podatke, ki jih zbira podjetje OIKOS, kajti to je trenutno največja zbirka podatkov o odlagališčih odpadkov pri nas, po splošnem prepričanju najprimernejša metodologija za zbiranje in je priporočena s strani MVOUP že tri leta. Kljub temu, da izhajamo iz OIKOS-ovega formata, pa smo poskrbeli za to, da je prenos iz drugih formatov dobro definiran, poleg aplikacije so namreč izdela- 
ni "Kriteriji za ocenjevanje kvalitete podatkov" in "Navodila za vnos podakov", s katerimi določimo kateri podatki so primerni za konverzijo oziroma dovolj dobri, da izboljšajo informativnost podatkovne baze (npr. podatki brez koordinat ali brez velikosti odlagališča so neuporabni).

\section{APLIKACIJA ZA POVPRAŠEVANJE PO PODATKIH}

Kljub temu, da je GeoSQL eden najenostavnejših GIS izdelkov na tržišču, vendarle zahteva določeno znanje in izkušnje. Za uporabnike podatkovne baze, ki jih zanimajo le najosnovnejša povpraševanja (odlagališča v določeni teritorialni enoti in izbor odlagališč določene velikosti) je bila izdelana aplikacija, ki preko menujev omogoči laiku delo s podatkovno bazo. Zaradi GeoSQL-ove popolne odprtosti lahko izdelana vprašanja hitro prilagodimo, tako da je aplikacija zelo koristen pripomoček tudi za postavljanje zahtevnejših vprašanj.

\section{POVEZAVA $Z$ DRUGIMI PODATKOVNIMI BAZAMI}

Pomembna lastnost vseh GIS orodij je ta, da lahko eno podatkovno bazo obravnavamo kot sloj, ki ga lahko polagamo preko drugih slojev in tako povežemo informacije. Tako lahko tudi podatke o odlagališčih povežemo $z$ drugimi (npr. geološka podlaga) in postavljamo vprašanja tipa "pokaži odlagališča, ki ležijo na produ". GIS pozna lokacijo odlagališča in preveri ali je točka znotraj lika, ki označuje prod. Za povezovanje $z$ drugimi bazami je potrebno boljše poznavanje GeoSQL-a, način povezave pa je močno odvisen od podatkov, $\mathrm{ki}$ jih povezujemo, tako da ne moremo podati splošnih receptov.

\section{EKSPERTNI SISTEM ZA PRIORITETIZACIJO SANACIJE ODLAGALIŠČ ODPADKOV}

Ob opisu GIS za odlagališča naj omenim še to, da pripravljamo ekspertni sistem, ki bo znal na podlagi popisa odlagališč razvrstiti odlagališča v pet kategorij nevarnosti za okolje in jih urediti znotraj posameznih razredov. Sistem bo znal obdelovati tudi nepopolne podatke in pojasniti svoje odločitve. To bo ena prvih aplikacij umetne inteligence na tem področju $v$ Sloveniji in upamo, da se bo izkazala za koristno orodje pri uporabi zbranih podatkov. Za uspešen nadzor odpadkov bo namreč potrebno ne le zbiranje podatkov, temveč predvsem učinkovita interpretacija in ukrepanje na podlagi pridobljenih informacij.

\section{ZAKLJUČEK}

Sloj odlagališč odpadkov je pri GIS v funkciji varovanja okolja in planiranja $v$ prostoru vsekakor nujen. Naj tu še navežemo na prispevek Marka Krevsa in Igorja Jurinčiča $v$ tem zborniku: Primer uporabe GIS za iskanje 
možnih virov onesnaženja na krasu. Avtorja problemsko opredelita možno onesnaževanje vodnega vira na krasu. Za analize onesnaženja je sloj odlagališč odpadkov prav gotovo najpomembnejša podlaga za lociranje virov onesnaženja.

GIS za upravljanje podatkovne baze odlagališč odpadkov je nedvomno korak naprej $\mathrm{v}$ uporabnosti in informativnosti zbranih podatkov. Ne le, da grafična predstavitev podatkov pove bistveno več kot samo besedilo, pomemben element je predvsem možnost povezovanja podatkov o odlagališčih $\mathrm{z}$ drugimi podatki. Ko bo zaživela izmenjava podatkov med GIS, se nam bodo odprle možnosti uporabe vseh podatkov o okolju na podlagi katerih bomo lahko sprejemali optimalne odločitve. To pa je tudi namen vsakega informacijskega sistema.

\section{LITERATURA IN VIRI}

Baza podatkov o odlagališčih odpadkov, stanje 1.10.1992 (3591 zapisov), Oikos, Ljubljana.

Gisdata Zagreb, Oikos Ljubljana 1991: Pilotna študija GIS za vodovarstveno območje izvira Rižana, Domžale, 6.

Environmental Systems Research Institute: Integration of Geographic Information Technologies, Arc News, Redlands (CA) USA, 1989, s. 3.

Prisley, S.P. 1986: Commercial GIS for natural resources management: What a maneger needs to know, USGS, Anchorage (AS) USA, 11.

Stritih, J., Šebenik, I. 1992: Illegal dumpsites in Slovenia, International symposium on environment contamination in Central and Eastern Europe, Budapest, 5.

Špendl, R. 1992: GIS za kataster divjih odlagališč odpadkov, Strokovno posvetovanje Divja odlagališča odpadkov v Sloveniji, Domžale, 2.

Tehnična dokumentacija GIS za upravljanje podatkovne baze odlagališč odpadkov, OIKOS, MVOUP, Ljubljana, 1992. 